\title{
Retirement Age Farmers' Exit and Disinvestment from Farming
}

\author{
Bretford Griffin ${ }^{1}$, Valentina Hartarska ${ }^{2,3}$ \& Denis Nadolnyak ${ }^{2}$ \\ ${ }^{1}$ Consumer Product Safety Commission, Bethesda, MD, USA \\ ${ }^{2}$ Department of Agricultural Economics and Rural Sociology, Auburn University, USA \\ ${ }^{3}$ Department of Finance, Auburn University, USA \\ Correspondence: Valentina Hartarska, Department of Agricultural Economics and Rural Sociology, 208 Comer \\ Hall, Auburn University, Auburn, AL 36830, USA. Tel: 1-334-844-5666. E-mail: hartarska@ auburn.edu
}

Received: October 23, 2019

Accepted: November 29, 2019 Online Published: November 30, 2019

doi:10.5539/ijef.v11n12p136

URL: https://doi.org/10.5539/ijef.v11n12p136

\begin{abstract}
The aging of farmers in the US today coincides with fluctuating incomes resulting from recent market price volatility and policy changes. We evaluate how farmers' retirement or exit, as well as their disinvestment from farming in preparation for retirement, are affected by economic and demographic factors. Exit and disinvestment are modeled as the outcome of intertemporal utility maximization, and farm-level data from the Census of Agriculture are used to estimate the probability of retirement-age farmers' exit and disinvestment for the 1992-2012 period. The results show that farm size matters the most, with larger farms less likely to exit but more likely to disinvest and scale back, presumably to a new optimal size. Demographic factors such as gender, race, and age have statistically significant but relatively small impacts. Regional differences, the size of the non-farm economy, and opportunities to diversify income also affect exit. However, flow economic variables, such as current year return-on-assets and agricultural support payments, are not associated with exit and disinvestment. Given that US farmers are now facing significant income volatility, the findings point to a level of resilience. The results suggesting that current and recent income fluctuations are less likely to drive the exit of retirement age farmers have important policy implications.
\end{abstract}

Keywords: retirement, farmers, exit from farming, disinvestment

JEL codes: Q10, Q12

\section{Highlights}

- Larger farms are less likely to exit and more likely to scale back operations;

- Income and government payments do not affect exit or disinvestment;

- Demographic factors, as well as size of the local non-agricultural economy, have small but statistically significant impact on retirement age farmers' exit and disinvestment;

- There is significant regional variability in retirement age farmers' exit and disinvestment rates.

\section{Introduction}

Recent data show that half of the US farmers are older than 58 , over half of the landlords are older than 65 , and these landlords are planning to transfer 91 million acres, or 10 percent of all agricultural land by 2020 (Agricultural Resources Management Survey, 2015). The aging of farmers suggests that they may soon disinvest or exit farming. The aging of the landowners is likely to affect the supply of agricultural assets. These trends have implications for prices of land and other assets, availability of agricultural credit, the speed of technological innovation, depopulation of rural areas, and the rural economy overall. In this paper, we evaluate what factors affect farmers' exit and disinvestment using Agricultural Census farm-level data for retirement age farm operators for the period of 1992-2012.

The demographic pressures are coinciding with pressures on farmers' profits and incomes. Since 2012, agricultural commodity markets have experienced significant price volatility which is unlikely to subside and, as a consequence, the pressure on farmers to retire may be accelerating (Newman \& McGroarty, 2017). The important questions are how farm profitability, together with other factors, affects operators' tendency to retire and whether farmers are more likely to exit or to rescale/disinvest and possibly wait out the bad times to get 
better income from their assets if prices improve in the future. We explore these issues by identifying the extent to which these factors affect retirement age farmers' exit, as well as their disinvestment in preparation for retirement.

We contribute to the literature in several ways. First, to explain exit and disinvestment, we use high quality individual farm data from the Census of Agriculture over 1992-2012. Most of the previous work on farm business survival and farmer exit is dated, spanning earlier periods, or uses a single Agricultural Resource Management Survey (ARMS) dataset from 2001 (e.g., Goetz \& Debertin, 2001; Mishra et al., 2010; Mishra et al., 2014; Key \& Roberts, 2006). Also, the existing literature on farmer retirement usually studies a single industry (e.g., dairy), state (e.g., Pennsylvania), or region, and thus lacks the breadth of analysis that may be more helpful for broader policy purposes to address issues stemming from the demographic transition presently underway. Unlike the previous work, we focus on the entire population of retirement age farmers in the US.

We frame the exit and disinvestment decisions as retiring farmers' intertemporal utility maximizing choices. In the empirical part, we first summarize the characteristics of exiting and disinvesting farmers using the Census data. Next, we specify a probit model for exit and disinvestment as a function of the variables suggested by the theory and by empirical evidence. Our results show that neither exit nor disinvestment are related to flow variables such as return on assets or to government payments. Farms with larger assets, family farms, and those in livestock production are less likely to exit and disinvest while farms with sales of more than $\$ 250,000$ are less likely to exit but more likely to disinvest possibly targeting a smaller production scale at retirement age. We find that demographic variables matter. Retirement age minority farmers are 11 percent more likely to exit, female farmers are slightly more likely to exit (retire) but slightly less likely to disinvest, while age affects the retirement decision in a non-linear fashion. Finally, farmers working off-farm have a statistically significant but only slightly smaller exit probability perhaps because, at retirement age, alternative job opportunities are not an important reason for exiting. The relative size of the regional non-agricultural economy that captures the tradeoffs between farming and other occupations reduces the probability of exit but increases disinvestment.

The following section summarizes the relevant literature, Section 3 develops the conceptual model, Section 4 describes the data, Section 5 discusses the results, and Section 6 concludes.

\section{Relevant Literature}

This paper is related to the work identifying what factors affect farmers' exit, including scaling back and through retirement, as well as to the broader literature on firm exit.

The most recent exit rates estimates for retirement age farmers are provided in Katchova and Ahearn (2017) who compute exit rates for various categories including farmers older than 65 using linked-farm and cohort approach and the Census Data. Their results compare well with ours and show exit rates of $10.5 \%$ for farmers 65 years and older for the period of 1997-2002, 9.4\% for 2002-2007, and 9.6\% for 2007-2012. Estimates for the prior period of 1978-1997 by Hoppe and Korb (2006) show peak exit rates of 12-13\% for farmers older than 65, with larger farms less likely to exit. Yet, Gale (2003) reports somewhat different results showing that the exit rate among farmers older than 65 dropped from 8.4 to 6.2 percent between 1978 and 1997. Gales' explanation that improved farmer health and the use of new technology, as well as fewer younger generation heirs interested in farming, contributed to slower exit rates is consistent with our results. Recent work on the exit of beginning farmers in the US shows that a variety of socio-economic, financial, and climate variables affect the probability of beginning farmer exit. However, while studies show that exit rates of retirement age farmers vary in time, they do not provide direct evidence on how economic and demographic factors correlate with and affect farm exit. Our work fills in this gap.

Research outside economics looks at the challenges and tradeoffs of selling or exiting the farm business and describes how farmer demographic characteristics, social constructs, family expectations, successor identity, early childhood socialization, etc., all combine to affect farm exit (Kuehne 2012; Fisher \& Burton, 2014). This work is typically case studies or studies based on survey data and thus faces the challenges of obtaining reliable data on sensitive financial and family circumstances. In the economic literature, there are very few nationally representative studies on the topic and work is often focused on the economic aspects of transferring ownership and retirement planning in the context of a smaller group of farmers within a commodity, region, etc. Examples include several studies of Pennsylvania and Maryland and dairy farms (Stokes, 2006; Tauer, 2006; Kimhi \& Lopez, 1999).

Another strand of literature finds that rural growth and farmers' incomes are linked to access to credit, suggesting that exit may be affected by ability to finance the transfer of assets (Nadolnyak, Hartarska, \& Shen, 2016, 2017). Earlier research on farm succession by economists was mostly in the context of how decisions are 
affected by tax considerations (Boehlje \& Eisgruber, 1972; Tauer, 1985; 1989; Harlin, 1992) or of succession of entering farmers trying to overcome borrowing constraints, at least in commercial farms (Tweeten \& Zulauf, 1994). Further studies evaluated the impact on exit, retirement related scaling back, and management transfer decisions of government policies, support payments, and alternatives for maximizing retirement benefits, as well as profitability and availability of off-farm work. For example, Kimhi (1994) highlighted the role of demographic factors and found that the optimal time of the farm business transfer to heirs is decreasing in parental age and depends on parents' productivity decline, while operators' off-farm employment increases the likelihood of the transfer. A transfer at an optimal time can also serve as insurance and secure the parents' retirement income (Pesquin, Kimhi, \& Kislev, 1999).

The literature on the management transfer decisions and exit has paid particular attention to the role of farmer demographics, farm and non-farm assets, and government payments and off-farm work. Mishra, El-Osta, and Shaik (2010) found that farm operator age, education, off-farm work by operator or spouse, as well as expected household wealth, geographic location, and government policies were all significant indicators in the choice of a successor. This role of demographics and government policies in the choice of family or non-family successor is also explored in Mishra and El-Osta (2008) who found impacts of polices, family wealth, and diversification of retirement savings.

Government payments and their decoupling from production decisions also influence farm rescaling choices and exit. For example, Key and Roberts (2006) show that increase in direct payments had a small but statistically significant negative impact on exit and that the magnitude increased with farm size. At the same time, larger debt to asset ratio was associated with an increased hazard rate. Similar results are reported in Mishra et al. (2014) and Pietola et al. (2003). Kazukauskuas et al. (2013) found that decoupling government payments for production decreased the overall exit rates but led to an increase in disinvestment in land and machines suggesting that government policies could allow an optimal rescaling of production, while also facilitating the exit of failing or aging farms. In a recent paper, May et al. (2019) argue that payments offered young farmers by the EU to stay in farming influence their willingness to stay indirectly through impacts on non-economic incentives such as community integration and participation in decision making.

Research on farmer exit outside the US shows that the drivers of retirement and exit differ by country. Kimhi and Bollman (1999) compare exit patterns of farmers in Canada and Israel and find that country specific institutional differences affect the speed of exit of retirement age farmers (larger in Canada) and that the impact of farm size on exit depends on institutional structure. Van Asseldonk et al. (2010) show significant differences in the Dutch farmers' long-term retirement investment, as well as lack of impact of some structural and objective parameters on retirement option choices. More recent studies in other countries include the stay-exit intention of livestock farmers in Chile emphasizing the role of expectations and social aspects of rural society (Leal, Lansink, \& Saatakmp, 2018), review of recent findings on entry and exit of farmers across the EU (Viaggi, 2019), and the importance of autonomy in farm exit decisions in Australia (Peel et al., 2019).

In a study of the financial vulnerability of firms in the US, Gutter and Saleem (2005) find that farmers rely too much on farming as a source of income and wealth and that, relative to other business owners, farmers are the most financially vulnerable and least likely to meet long-term objectives for retirement. Their article highlights how idiosyncratic risks, such as commodity price fluctuations and weather, can affect farmers' short-term finances and retirement goals. This is exactly what aging farmers could be experiencing currently. For example, Lee, Nadolnyak, and Hartarska (2017) find that annual and seasonal temperature have non-linear impact on agricultural labor supply in the US. Also, the value of farmland was found to depend on seasonal temperature and precipitation which may drive geographical patterns of farm exit. Moreover, Li, Nadolnyak, and Hartarska (2019) show that, in Florida, farm profitability together with climate change related natural hazards affect farmland conversion and consequently farmers' decisions to exit. Thus, understanding what affects farmers' retirement and scaling back using national level data and a relatively longer time period is very important.

The present work is also related to the farm exit in general and not only of retirement age farmers. Goetz and Debertin (2001) find that, while off-farm labor and government payments do not seem to affect exit overall, if US counties are grouped by whether they are losing or gaining farmers, off-farm work and government payments matter. In particular, the speed of exit in counties that lose farmers is higher the more dependent these counties are on agricultural subsidies.

Finally, this paper is related to the literature on the relationship between off-farm work and capital accumulation for which we have evidence of a negative association (Ahituv \& Kimhi, 2002). Farm households' needs, consumption, and investment can drive decisions to pursue off-farm employment regardless of how the money is 
to be spent (Harris \& Mishra, 2019). Huffman (1980) also finds that the volume of farm output and farmer demographic characteristics affect off-farm labor.

\section{Methodology}

The theoretical basis for the empirical model is a constrained inter-temporal maximization problem that results in a value function of not exiting (Pietola et al., 2003; Blundell \& MacCurdy, 1999; Kimhi \& Bollman, 1999). The farmer maximizes the present value of current and future utility of consumption and leisure,

$$
V_{t}=\sum_{\tau=t} \gamma_{\tau \mid t} U\left(C_{\tau}, L_{\tau}\right)
$$

where $\mathrm{C} \tau$ and $\mathrm{L} \tau$ are consumption and leisure at a future time $\tau$ and $\gamma \tau \mid t$ is the discount factor from $\tau$ to $t$. The general form of the intertemporal budget constraint is

$$
\sum r_{\tau \mid t} C_{\tau}=\sum r_{\tau \mid t}\left(w_{\tau}\left(1-L_{\tau}\right)+F_{\tau}\right)+A_{t}
$$

where $A t$ is the net value of assets at time t, w $\tau$ is the off-farm wage rate, per period time endowment is assumed to be $1, \mathrm{~F} \tau$ is gross farm income, and $\mathrm{r} \tau \mid \mathrm{t}$ is the market discount rate from $\tau$ to $\mathrm{t}$ which is different from $\gamma \tau \mid t$. The specific form of the budget constraint depends on the exit choice (no on-farm income in case of exit, which changes the optimal labor-leisure allocation). Assuming that the exit decision is irreversible, the value of exiting can be defined as $V t E$ as (1) maximized with respect to (2) excluding $F \tau$ which, in a reduced form, is a function of the variables affecting on- and off-farm income and utility that include individual farmer attributes as well as institutional and locational factors. The present value of utility from not exiting (staying) at the end of current period $t$ is

$$
V_{t}^{S}=U\left(C_{t}, L_{t}\right)+\gamma_{t+1} \max \left(V_{t+1}^{S}, V_{t+1}^{E}\right)
$$

This setup can also accommodate descaling or disinvestment by a sale of assets that may be optimal before exiting, depending on consumption and leisure preferences and their changes in time. The difference between the values of staying and exiting, $W t=V t E-V t S$, can be called a tendency to exit and is determined by the same variables that determine $V t E$ and $V t S$. Equation (3) suggests that $W t$ increases with variables that positively impact the current off-farm utility and decreases with variables that positively impact on-farm utility and future off-farm utility. It is important that this formulation does not posit definitive a priori impacts on the exit choices. The ambiguity arises from the conflicting direct and indirect effects of the variables. Examples include changes in off-farm labor market conditions that affect both current and future off-farm utility, personal characteristics such as age and education that affect both states, and farm income that increases the on-farm utility but, in time, may lead to changes in labor-leisure allocation favoring exit. Defined as above, the tendency to exit specifies the exit decision rule as an index function:

$$
E_{t}=\left\{\begin{array}{l}
1 \text { if } W_{t}>0(\text { farmer decides to exit in period } t) \\
0 \text { otherwise }(\text { farmer decides not to exit in } t)
\end{array}\right.
$$

The first order estimable approximation of the tendency is

$$
W_{t}=\beta X_{t}+\varepsilon_{i}
$$

where $\mathrm{Xt}$ is the vector of the variables hypothesized to directly affect current and future on- and off-farm utility as well as shifters such as personal and location-specific attributes and institutional factors and $\varepsilon i$ is the approximation error. If $\varepsilon i$ is assumed to be standard normal, the parameter coefficients in $\beta$ can be estimated using standard Probit with the cumulative in the log-likelihood being standard normal over $(-\infty, \beta \mathrm{Xt})$. In this paper, the probability of observing exit/disinvestment is modeled as:

$$
E^{*}=\boldsymbol{X}_{i}^{\prime} \beta+\varepsilon_{i}, E=1 \text { if } E^{*}>0 \text {, otherwise } 0
$$

where $\mathrm{E}$ is a binary exit variable. The variables in $\mathrm{X}$ are determined by the relevant empirical findings and include measures of profitability, on- and off-farm income and demographic variables, agricultural subsidies, and macroeconomic and regional factors.

\section{Data}

We use the latest available farm-level Census of Agriculture data from surveys conducted in 1992, 1997, 2002, 2007, and 2012. State GDP data come from the Bureau of Economic Analysis. The Census data contain retirement age farmers and ranchers whom we define as principal farm operators 60 years or older with more than $\$ 50,000$ in total annual production. The primary reason for exit from farming for this demographic group is assumed to be retirement, whereas disinvestment is assumed to be in preparation for retirement (Note 1).

The dependent variables are exit from farming and disinvestment. The exit variable takes the value of 1 if, in the next Census survey data, there is no record of that individual farmer ID and zero otherwise. While completion of the Census questionnaire is mandatory, a measurement error is possible for a small number of observations if a 
working operator fails to comply and fill in a Census questionnaire for a Census year prior to the end of our sample period (2012). We adjust for this by taking the final year of the operator reports, allowing for reporting gaps between 1992 and 2012. Thus, we do not code farmers as exiting if they skipped a participation in one Census round but participated later on. The relatively large number of observations in the dataset helps overcome the problem of possible measurement errors in the dependent variable.

The disinvestment from farming variable is also a dummy that takes the value of one if the land owned at Census year $\mathrm{t}$ is less than $80 \%$ of the land owned in the previous Census year. This benchmark is selected because the average percentage of the land sold was a little above 20 percent in all Census intervals so we assume that above average sales represent intentional scaling back attributed to preparation for retirement, whereas selling smaller amounts of land are more likely to be used to cover regular financial obligations (debt or intergenerational transfers) or to take advantage of temporary market opportunities. Finally, scaling back at the age of over 60 may be due to re-optimizing size given farmers' overall health and physical strength (Note 2). The disinvestment variable may also have measurement issues similar to the exit variable resulting from farmer's failure to complete the mandatory Census questionnaire and, therefore, we also skip gaps to find farmers who disinvested from the last time they reported. As before, we assume that the possible measurement error is not systematic and, thus, can be overcome by a large number of observations.

The independent variables include farm economic indicators such as return on assets (ROA), total assets (LnAssets), a family farm dummy (FAMILY), and a dummy for livestock type farm (LIVESTOCK), as well as whether the farm received government payments (GPAYMNT). Farmer demographic characteristics include age (AGE), gender (FEMALE), and race (WHITE) dummies and whether the operator worked off the farm. The specifications also control for available off-farm employment opportunities through variables measuring the share of the state non-agricultural GDP (NONAGSHARE), the production region, and Census Year. The variable definitions are listed in Table 1.

Table 1. Description of variables

\begin{tabular}{ll}
\hline Variable & Description \\
\hline Exit & Dummy: 1 if respondent exits farming \\
Disnivest & Dummy 1 if disinvested (land sale above the average rate of >20\% ) \\
& Farm Characteristics \\
ROA & Return on Assets; (Value of Production -Expense) /Assets \\
Assets & Sum of VLAB and MACHVAL $(\$ 1,000)$ \\
LnASSETS & Natural log of assets \\
High Sales & Dummy: One if Sales > \$250,000, zero otherwise \\
Livestock & Dummy: One if operation's sales is primarily livestock, zero otherwise \\
Family & Dummy: One if family operation, zero otherwise \\
GovPayment & Government payment dummy \\
& Operator Characteristics \\
Age & Age of Principal Operator \\
White & Dummy: One if operator is a white, zero otherwise \\
Female & Dummy One if Principal Operator is Female, zero otherwise \\
WrkOffFarm & Dummy: One if operators worked off farm, zero otherwise \\
& Regional Characteristics \\
NonAhShare & 1- Agriculture's share of State GDP \\
Regional Dummies & AP = Appalachian, CB = Corn Belt, DLT = Delta, LS = Lake States, MTN = Mountain, NTE = \\
& Northeast, NP = North Plains, PAC = Pacific, SE = Southeast, SP = South Plains \\
Census Year & Time \\
& Census Year of observation \\
\hline
\end{tabular}

Data in Table 1 show that the proportions of exiting non-hobby farmers older than 60 in our sample are very similar to data published in other work. For example, using a different methodology employing aggregate cohorts, Katchova and Ahearn (2017) compute exit rates for farmers older than 65 that, as expected, are slightly higher than the exits rates for our slightly younger cohort (10.5, 9.4, and 9.6 vs. 7, 6.6 and 8 for the respective periods of 1997-2002, 2002-2007, and 2007-2012). Thus, while we cannot employ the cohort method since we need individual observations to use in the regression analysis, the similarities in the exit rates are reassuring, especially in the context of possible dependent variable measurement errors in the data that includes the entire population. 


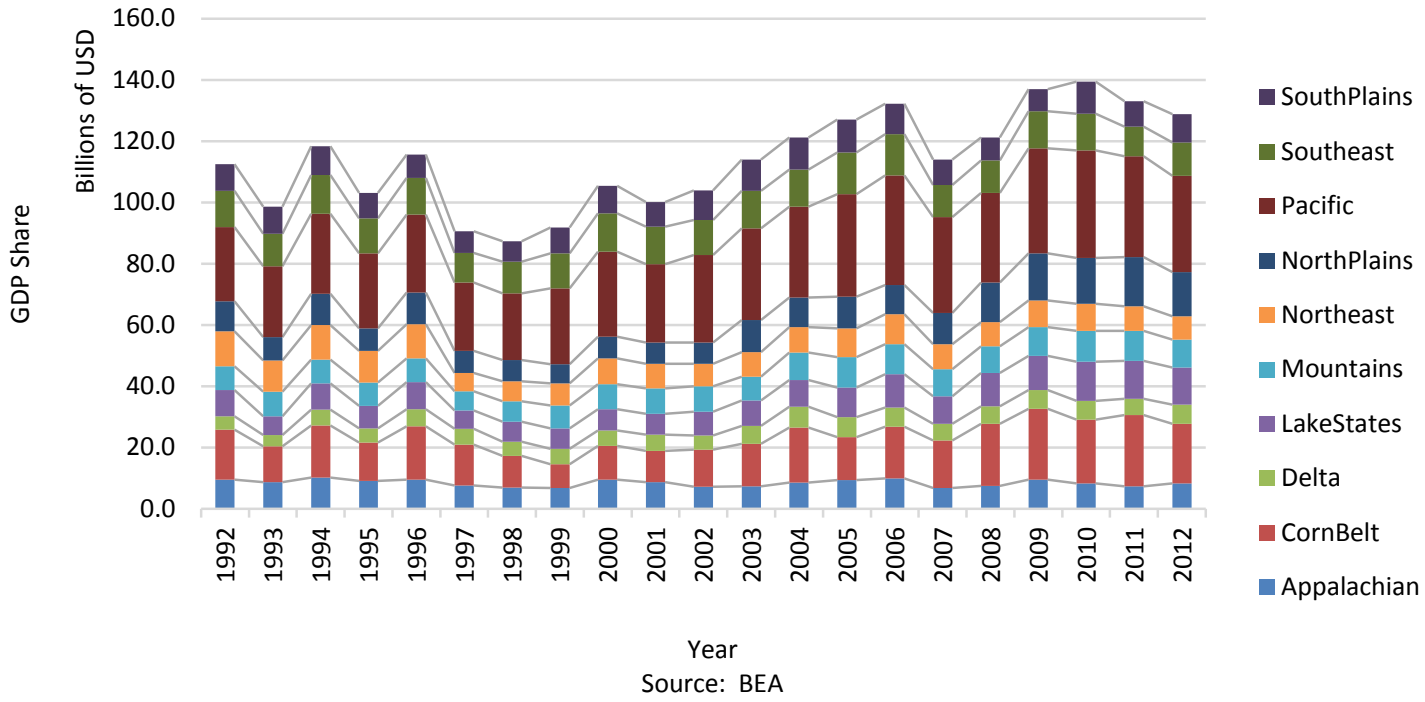

Figure 1. Regional contribution to GDP in agriculture

Figures 1 and 2 show the aggregate trends in agricultural GDP by regions and in time. The production regions that we analyze and control for in the regressions are Southeast, Appalachia, Corn Belt, Delta, Lake States, Mountains, Northeast, Northern Plains, Pacific, and Southern Plains. Figures 1 and 2 show that the regional GDP and the shares of agricultural GDP generally moved in the same direction preserving existing regional differences throughout the study period.

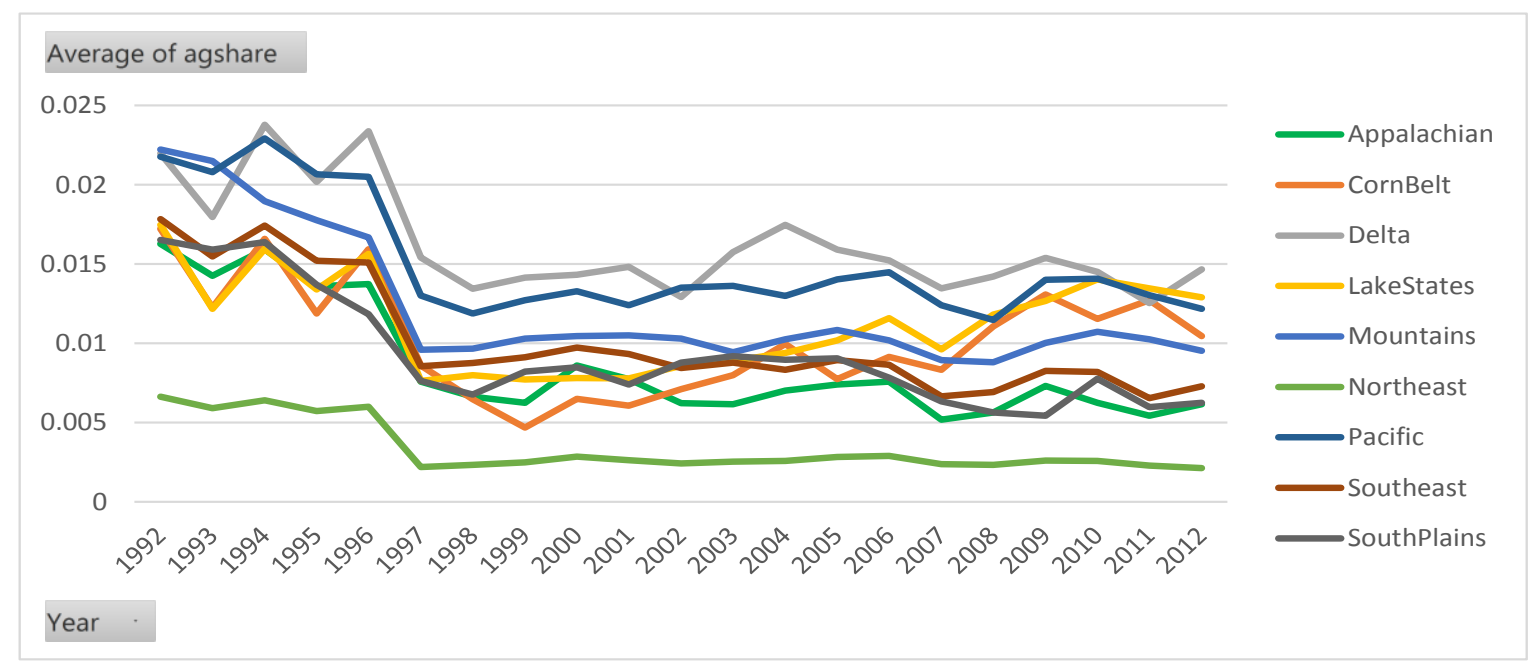

Figure 2. Agriculture share of GDP

The actual values are in Table 2 that shows all key variables' means and patterns of change by Census year. 
Table 2. Variable means by census year (retirement age farmers with sales more than $\$ 50,000$ )

\begin{tabular}{|c|c|c|c|c|}
\hline & 1997 & 2002 & 2007 & 2012 \\
\hline \multicolumn{5}{|l|}{ Dependent Variables } \\
\hline Exit rate $(\%)$ & 9.4 & 8.8 & 8 & 9 \\
\hline Disinvestment & 19 & 22 & 22.8 & 22.5 \\
\hline Average percentage of land sold & 24 & 28.4 & 28.1 & 27.5 \\
\hline \multicolumn{5}{|l|}{ Farm Characteristics } \\
\hline$R O A(\%)$ & 5.6 & 4.4 & 2.1 & 0.01 \\
\hline Assets (\$'000) & 663 & 807 & 540 & 649 \\
\hline LnAssets & 5.534 & 5.674 & 5.427 & 5.464 \\
\hline HighSales $(>\$ 250,000)$ & 0.016 & 0.016 & 0.023 & 0.033 \\
\hline Livestock (main production) & 0.524 & 0.506 & 0.460 & 0.449 \\
\hline Family (farm) & 0.869 & 0.899 & 0.860 & 0.866 \\
\hline GovPayment & 0.709 & 0.777 & 0.751 & 0.818 \\
\hline \multicolumn{5}{|l|}{ Operator Characteristics } \\
\hline Age (years) & 69.7 & 69.7 & 69.8 & 69.9 \\
\hline White & 97.51 & 97.11 & 95.9 & 95.4 \\
\hline Female & 0.91 & 0.95 & 1.16 & 1.29 \\
\hline WrkOffFarm (PO worked off farm) & 0.400 & 0.296 & 0.479 & 0.456 \\
\hline \multicolumn{5}{|l|}{ Regional Characteristics } \\
\hline NonAgShare (of GDP) & 0.987 & 0.988 & 0.988 & 0.986 \\
\hline \multicolumn{5}{|l|}{ Regional Dummies } \\
\hline Appalachian & 0.148 & 0.146 & 0.136 & 0.130 \\
\hline Corn Belt & 0.184 & 0.187 & 0.175 & 0.175 \\
\hline Delta Region & 0.055 & 0.058 & 0.057 & 0.056 \\
\hline Lake States & 0.081 & 0.084 & 0.084 & 0.082 \\
\hline Mountains & 0.061 & 0.059 & 0.074 & 0.083 \\
\hline Northeast & 0.064 & 0.061 & 0.066 & 0.067 \\
\hline North Plains & 0.081 & 0.080 & 0.076 & 0.075 \\
\hline Pacific & 0.075 & 0.073 & 0.074 & 0.078 \\
\hline Southeast & 0.085 & 0.085 & 0.083 & 0.082 \\
\hline \multirow[t]{2}{*}{ South Plains } & 0.163 & 0.165 & 0.170 & 0.169 \\
\hline & 1997 & 2002 & 2007 & 2012 \\
\hline \multicolumn{5}{|l|}{ General Data Characteristics } \\
\hline Retirement Age Farmers & 35.7 & 37.5 & 42.6 & 47.6 \\
\hline \multicolumn{5}{|l|}{ (\% 60 years or older to/ all famers) } \\
\hline Farmers over 60 years $(\#)$ & 588,126 & 557,482 & 649,247 & 657,413 \\
\hline Disinvested (sold land, \#) & 147,685 & 175,534 & 214,372 & 225,844 \\
\hline Disinvested with sales $>\$ 50,000$ & 118,319 & 131,075 & 155,061 & 159,806 \\
\hline Average $\%$ land sold & 24.0 & 28.4 & 28.1 & 27.5 \\
\hline All Farmers with sales $>\$ 2,000$ & $1,649,544$ & $1,486,868$ & $1,523,825$ & $1,382,099$ \\
\hline
\end{tabular}

Table 2 shows that about $88 \%$ of the retirement age operators run family farms (as opposed to national average of $83 \%$ ), while about $50 \%$ specialize in livestock production with their share decreasing over time possibly at the expense of mixed or other specialized production units (Note 3). Only up to 3\% of the farmers fall in the category of high sales (over $\$ 250,000$ ) with the share of retirement age farmers in that category continuously increasing confirming the consolidation trend in the US agriculture. We note the decline in profitability as measured by ROA of retirement age farmers from $5.6 \%$ in the 1992 Census to about $0 \%$ percent in 2012. The retirement age farmers' assets varied between $\$ 500,000$ and $\$ 800,000$ over the study period. Interestingly, in this age group, a large share of farmers seem to receive government payments (about double the national average in 2007 for example) and this number has not changed much in time. The average age of this group is about 70 years and was stable suggesting that many farmers retire soon after they become eligible for retirement. Retirement age farmers own on average about 350 acres, which is smaller than the 398 acre average for all farms. 
Table 3 presents the differences in the means between the group of farmers who disinvested and the group that did not (Note 4). Farmers who disinvested were about a year older than those that did not, and owned over 100 fewer acres the year after disinvestment. In all Census years, higher proportions of farmers were disinvesting in the Southeast, the Mountains, and the Lake States production regions. There is evidence that the disinvesting farmers were more likely to be family farms and the principal operators were less likely to have worked off farm but the difference is very small.

Table 3. Statistically significant mean differences between farmers who disinvested (sold more than $20 \%$ of their land in Census Year t-1) and those that did not

\begin{tabular}{|c|c|c|c|c|}
\hline & 1997 & 2002 & 2007 & 2012 \\
\hline \multicolumn{5}{|c|}{ Farm Characteristics } \\
\hline$R O A$ & 0.003 & $0.058^{*}$ & -0.002 & \\
\hline Assets & $-80.3 *$ & 5.20 & $18.4^{*}$ & -3.80 \\
\hline lnAssets & $-0.045^{*}$ & $-0.025^{*}$ & $-0.04 *$ & $-0.118^{*}$ \\
\hline HighSales & $-0.002 *$ & $0.004^{*}$ & $0.007 *$ & $0.006^{*}$ \\
\hline Livestock & $0.014^{*}$ & $0.013^{*}$ & $-0.008 *$ & $-0.006^{*}$ \\
\hline Family & $0.016^{*}$ & $-0.010^{*}$ & $-0.012 *$ & $-0.021 *$ \\
\hline GovPayment & 0.372 & 0.046 & $-0.369 *$ & -0.141 \\
\hline \multicolumn{5}{|c|}{ Operator Characteristics } \\
\hline Age & $0.97 *$ & $0.93^{*}$ & $0.93^{*}$ & $0.97 *$ \\
\hline WrkOffFarm & -0.001 & $-0.023^{*}$ & $-0.007 *$ & $-0.010 *$ \\
\hline \multicolumn{5}{|c|}{ Regional Characterictis } \\
\hline NonAgShare & $0.0002^{*}$ & $0.0002 *$ & $-0.0005^{*}$ & $-0.0007 *$ \\
\hline Appalachian & $0.014 *$ & $0.007 *$ & $0.003^{*}$ & $-0.004 *$ \\
\hline Corn Belt & $-0.013 *$ & $-0.028^{*}$ & $-0.009 *$ & $-0.011 *$ \\
\hline Delta Region & $-0.001 *$ & $0.005^{*}$ & $-0.002 *$ & $0.004^{*}$ \\
\hline Lake States & $0.009^{*}$ & $0.004 *$ & $0.002^{*}$ & $-0.002 *$ \\
\hline Mountains & $0.014 *$ & $0.007 *$ & $0.006^{*}$ & $0.018^{*}$ \\
\hline Northeast & $0.003 *$ & $-0.003^{*}$ & $-0.002 *$ & $-0.005^{*}$ \\
\hline North Plains & $-0.004 *$ & $-0.002 *$ & $0.009^{*}$ & $0.009^{*}$ \\
\hline Pacific & $-0.002 *$ & 0.000 & $0.003^{*}$ & $-0.006^{*}$ \\
\hline Southeast & $0.004 *$ & $0.006^{*}$ & $0.004 *$ & $0.002^{*}$ \\
\hline South Plains & $-0.022 *$ & $0.004^{*}$ & $-0.014 *$ & $-0.007 *$ \\
\hline
\end{tabular}

Note. *Indicates significant at $\mathrm{P}=.05$. Positive values indicates Disinvestment > No disinvestment; Negative values indicated Disinvestment $<$ No disinvestment.

Further analyzing the statistically significant differences among the two groups shows no difference in ROA except for the year 2002 when those who disinvested had about 5.8\% higher ROA than those who did not. We also do not see systematic differences in assets size. The assets value was the same for farmers who disinvested as for those who did not in the Census years 2002 and 2012, but assets were $\$ 80,300$ less for those who disinvested in 1997 and $\$ 18,400$ less in 2007. Our data do not show differences in terms of government payments received except for farmers disinvesting between 2002 and 2007 when a much smaller proportion of them received government payments relative to those who did not disinvest.

More disinvesting farmers are located in regions with a higher share of agricultural GDP up to 2002 and in regions with a smaller share of agricultural GDP between 2002 and 2012. We find that, in general, disinvesting farmers were less likely to work off-farm but the difference between the two groups is very small. We also see that disinvesting farmers were more likely to be family farms up to 1997 but less likely to be family farms after that. Up to 2002, disinvesting farmers were more likely to be mostly in livestock production but that proportion decreased after 2007.

\section{Estimation Results}

Table 4 presents results from the Probit estimation for exit and disinvestment, with the first column containing the estimated coefficients and their significance and next column containing the marginal impacts at the mean. The regression diagnostics show satisfactory values and acceptable data fit. 
Table 4. Probit regression of exit and disinvestment for retirement age farmers

\begin{tabular}{|c|c|c|c|c|}
\hline \multirow[t]{2}{*}{ Variable } & \multicolumn{2}{|l|}{ RETIRE } & \multicolumn{2}{|l|}{ DISINVEST } \\
\hline & Coefficient Estimate & Marginal Effect & Coefficient Estimate & Marginal Effect \\
\hline Intercept & $\begin{array}{l}6.266^{* * * *} \\
(0.311)\end{array}$ & & $\begin{array}{l}-109.3 * * * \\
(1.699)\end{array}$ & \\
\hline \multicolumn{5}{|l|}{ Farm Characteristics } \\
\hline$R O A$ & $\begin{array}{l}0.008 \\
(0.007)\end{array}$ & 0.000 & $\begin{array}{l}-0.012 \\
(0.014)\end{array}$ & 0.000 \\
\hline lnAssets & $\begin{array}{l}-0.123 * * * \\
(0.004)\end{array}$ & -0.671 & $\begin{array}{l}-0.015^{* *} \\
(0.005)\end{array}$ & -0.084 \\
\hline HighSales & $\begin{array}{l}-0.049 * * * \\
(0.010)\end{array}$ & -0.043 & $\begin{array}{l}0.089 * * * \\
(0.013)\end{array}$ & 0.079 \\
\hline Livestock & $\begin{array}{l}-0.125^{* * *} \\
(0.007)\end{array}$ & -0.056 & $\begin{array}{l}-0.068 * * * \\
(0.009)\end{array}$ & -0.031 \\
\hline Family & $\begin{array}{l}-0.079 * * * \\
(0.007)\end{array}$ & -0.069 & $\begin{array}{l}-0.055^{* * *} \\
(0.009)\end{array}$ & -0.048 \\
\hline GovPayment & $\begin{array}{l}0.002 \\
(0.030)\end{array}$ & 0.002 & $\begin{array}{l}-0.047 \\
(0.044)\end{array}$ & -0.038 \\
\hline \multicolumn{5}{|l|}{ Operator Characteristics } \\
\hline Age & $\begin{array}{l}-0.070^{* * *} \\
(0.007)\end{array}$ & & $\begin{array}{l}0.017 \\
(0.010)\end{array}$ & \\
\hline Age Squared & $\begin{array}{l}0.001 * * * \\
(0.000)\end{array}$ & & $\begin{array}{l}-.000 \\
(0.000)\end{array}$ & \\
\hline White & $\begin{array}{l}-0.189 * * * \\
(0.048)\end{array}$ & -0.107 & $\begin{array}{l}-0.107 \\
(0.078)\end{array}$ & -0.189 \\
\hline Female & $\begin{array}{l}0.2406^{* * * *} \\
(0.014)\end{array}$ & 0.013 & $\begin{array}{l}-0.132 * * * \\
(0.021)\end{array}$ & -0.024 \\
\hline WrkOffFarm & $\begin{array}{l}0.016^{* *} \\
(0.007)\end{array}$ & 0.007 & $\begin{array}{l}0.019 * \\
(0.009)\end{array}$ & 0.009 \\
\hline \multicolumn{5}{|l|}{ Regional Characteristics } \\
\hline NonAgShare & $\begin{array}{l}-3.822 * * * \\
(0.179)\end{array}$ & -3.77 & $\begin{array}{l}6.94 * * * \\
(0.339)\end{array}$ & 6.84 \\
\hline Census Year & YES & & YES & \\
\hline Region & YES & & YES & \\
\hline $\mathrm{N}$ & 184,155 & & 184,155 & \\
\hline Sum of Weights & 205,912 & & 205,912 & \\
\hline Likelihood Ratio (P value) & $5,776(0.001)$ & & $5,848(0.001)$ & \\
\hline Wald (P value) & $5,658(0.001)$ & & $5,013(0.001)$ & \\
\hline Pseudo Chi2 & 0.26 & & 0.25 & \\
\hline
\end{tabular}

Robust standard errors in parentheses, $* * * \mathrm{p}<0.01, * * \mathrm{p}<0.05, * \mathrm{p}<0.1$.

We first examine the impact of flow economic variables or variables that reflect current economic performance. The results show that profitability of the farming operation (ROA) is not associated with exit or disinvestment. This suggests that farmers' current cash flow and incomes do not drive the exit decisions, which is an important policy relevant result. It is also in line with previous studies on non-retirement age farmers' exit (e.g., Mishra et al., 2014). Unlike other studies of exit in the entire farmer population (e.g., Mishra, El-Osta, \& Shaik, 2010, who use 2001 ARMS data) finding that government payment intensity slowed down the exit of family farms, we do not find that government payments affect either exit or disinvestment of retirement age farmers. Related work by Key and Roberts (2006) that also uses the Census data but for the earlier period of 1987-1997 finds very small statistically significant impact of government payments on farm business survival. On the other hand, Goetz and Debertin (2001) found that government payments as well as off-farm work do not affect exit using national level county data. However, within the group of counties that had lost farmers, the speed of exit was higher the more reliant farmers were on those payments.

At the same time, we find that the stock economic variables such as accumulated wealth matter. For example, farm size (LnAssets) has a large and statistically significant negative impact on exit rates with the marginal impact indicating that one percent increase in assets is associated with $0.67 \%$ lower probability of exit. Similarly, one percent increase in assets is associated with $0.08 \%$ lower probability of disinvestment at the mean. Several other size related variables influence exit and scaling back. Farms with sales more than $\$ 250,000$ are 4.3 percent 
less likely to exit farming than smaller scale operators which is in line with Mishra et al. (2014) who report that larger farms (sales over $\$ 500,000$ in 2001) have 1.6 percent lower probability of exit. At the same time, farms with larger sales are also 7.9 percent more likely to scale back which, for our sample, may suggest downsizing to reduce the workload because of the operator's age.

We find significant exit rate differences by the farm types. Compared to non-family farms, family farms have 6.9 percent lower probability of exit and 4.8 percent lower probability of scaling back, which probably highlights their stronger commitment to farming. Also, operators who are primarily livestock producers are 5.6 percent less likely to exit farming and 3.1 percent less likely to scale back relative to farmers in other types of agricultural production. This could be attributed to the fact that livestock producers are more vertically integrated and thus bound by longer term contractual obligations. They are also less likely to be hobby farmers and use different technology.

As expected, off-farm work by retirement age farmers is associated with increased probabilities of both exit and disinvestment although the magnitude is surprisingly small. Specifically, we find that families that work off-farm are about one percent more likely to exit farming than those who work on the farm full time and they also are about one percent more likely to disinvest in preparation for retirement. This small effect may be due to the categorical nature of the off-farm work variable. This result is different from previous work that finds that operators who work off-farm have a negative association with exit while operators whose spouse works off-farm have a positive association with exit (Mishra et al., 2014). Since our data do not distinguish between the two, it is possible that these two opposite effects offset each other.

We also find that, compared to male farm operators, female operators are 1.3 percent more likely to exit farming but are 2.4 percent less likely to scale back. According to the Census, the majority of women operated farms are less than 50 acres (54\% in 2012 compared to 39\% of all farms), which leaves them with little room to downscale. Also, it is possible that, once a retirement age female operator becomes a widow, she is more likely to sell the farm because it is hard to run it alone.

There are statistically significant differences in exit rates by race and age. During the study period, white farmers were 10.7 percent less likely to exit farming relative to minority farmers but did not differ in terms of disinvestment. This warrants further study and could be related to inter-generational dynamics and other factors that need to be identified. The age variable enters the regression non-linearly because farmers in the sample are 60 or older. Since farmer retirement typically happens at the ages of 62,65 , or 70 as defined by the social security eligibility for those who have paid in the system, farmers are less likely to exit in their early 60s but are more likely to exit in late $60 \mathrm{~s}$ and early $70 \mathrm{~s}$. The marginal estimates do not have a direct interpretation but support the notion of initially negative duration dependence that is slowly becoming positive as the age increases (Note 5). However, age is unrelated to disinvesting for retirement age farmers.

Similar to the sales category, the opportunity costs of farming as measured by the size of the non-agricultural economy's share of GDP have strong and divergent impacts on exit and disinvestment. We find that a one percent increase in the share of the non-agricultural sector was associated with 3.77 percent lower probability of exit from farming suggesting positive feedbacks from local non-agricultural economies (Note 6). At the same time, a similar increase in the non-agricultural sector is associated with 6 percent increase in disinvestment (or land sales) which may reflect taking advantage of higher land values in such areas, presumably before retirement.

In addition, consistent with work by Mishra et al. (2014), we find significant regional differences. Farmers from the Corn Belt, the Lake States, and the Northeast are less likely to disinvest, and the Northeastern farmers are more likely to exit relative to the base (Appalachia). The Delta States' farmers are more likely to disinvest and to exit, while the Mountain States and the Southeast are more likely only to disinvest (values not shown for formatting sake).

\section{Conclusions}

Understanding what factors affect exit and disinvestment of retirement age farmers provides insights into the issues of agricultural land use, rural development and depopulation, and can be helpful in designing agricultural policies. Farming in the US is undergoing significant demographic transition driven by the age dynamics of the farmer population. Latest data from the Census of Agriculture show that half of the U.S. farmers are 58 years or older and half of the landowners are 65 years or older. The 2014 ARMS data on farmers' intentions to exit farming and transfer land (presumably to retire) show that, by 2020, about 10 percent of agricultural land will likely change hands. In this paper, we estimate the probability of retirement age farmers' exit specified as an outcome of intertemporal utility maximization (Kimhi \& Bollman, 1999; Mishra, Fannin, \& Joo, 2014). We 
contribute to the recent literature by using individual farmer data from the latest available five Census rounds spanning the period of 1992-2012, which is a longer and more recent interval relative to previously published research on the topic.

Building on previous empirical work, we evaluate the impacts of a number of explanatory variables on two exit measures: actual exit and disinvestment (scaling back). Analyzing the likelihood of disinvestment allows us to learn about what farm operators do in preparation for retirement. We identify several factors associated with exit from farming, with the main differences in the tendency to exit coming from differences in the demographic and farm characteristics, as well as regional attributes. Our results are consistent with previous findings that farmers with larger operations are less likely to exit or disinvest with mean marginal impacts of size (assets) being - $0.67 \%$ and $-0.08 \%$. Retirement age farmers with large sales (more than $\$ 250,000$ ) are also more likely to disinvest. In addition, farm exit rates are lower but disinvestment is higher in regions with larger non-agricultural sectors, possibly indicating taking advantage of market conditions and land conversion for non-agricultural uses. For retirement age farmers, off-farm work has a minimal, although statistically significant, negative impact with operators with off-farm jobs only 1 percent less likely to exit than those who do not work off-farm. Similar small differences are found for demographic characteristics. For example, female farmers are one percent more likely to exit but two percent less likely to disinvest than male farmers. White farmers are 10 percent less likely to exit than the minority farmers.

The most surprising result is that, with the exception of farm size, flow economic variables such as return on assets and government payments are not associated with exit or disinvestment. The lack of impact of current economic performance suggests that farm transition during the study period was mostly determined by non-economic factors. While the impacts of demographic factors such as age, gender, and race are of small magnitude, the impacts of other factors not captured by the available data like adult children age and their education and occupation are likely to be larger. These results have important policy implications as the recent drop in farming profitability may be less of a catalyst to older farmers' exit than expected. While the interpretation that farmers' decisions to exit are driven mainly by wealth and demographics and not by direct contemporaneous economic performance indicators is plausible, it warrants further investigation. Some of these questions can be further addressed using the new 2017 Census of Agriculture data that will soon become available for research purposes. Furthermore, to address pressing and important policy issues related to farm exit and retirement, future research will also need to identify the factors that affect entry of new and beginning farmers, as well as the expansion of existing farms or farm entry and exit in general.

\section{References}

Agricultural Resources Management Survey. (2015). Farmland Ownership and Tenure: Results from the 2014 Tenure, Ownership, and Transition of Agricultural Land Survey.

Ahituv, A., \& Ayal, K. (2002). Off-farm work and capital accumulation decisions of farmers over the life-cycle: The role of heterogeneity and state dependence. Journal of Development Economics, 68(2), 329-353. https://doi.org/10.1016/S0304-3878(02)00016-0

Blundell, R., \& Thomas, M. (1999). Labor Supply: A review of alternative approaches. Chapter 27. Handbook of Labor Economics, 3(Part A), 1559-1695. https://doi.org/10.1016/S1573-4463(99)03008-4

Boehlje, M. D., \& Eisgruber, L. M. (1972).Strategies for the Creation and Transfer of Farm Estate. American Journal of Agricultural Economics, 54(4), 461-472. https://doi.org/10.2307/1239162

Fisher, H., \& Burton, R. (2014). Understanding Farm Succession as Socially Constructed Endogenous Cycles. Sociologia Rurales, 54(4), 417-438. https://doi.org/10.1111/soru.12055

Gale, H. F. (2003). Age-Specific Patterns of Exit and Entry in U.S. Farming, 1978-1997. Review of Agricultural Economics, 25(1), 168-186. https://doi.org/10.1111/1467-9353.00052

Goetz, S. J., \& David, L. D. (2001). Why Farmers Quit: A County-Level Analysis. American Journal of Agricultural Economics, 83(4), 1010-1023. https://doi.org/10.1111/0002-9092.00226

Gutter, M. S., \& Tabassum, S. (2005). Financial vulnerability of small business owners. Financial Services Review, 14, 133-147. https://doi.org/10.1016/j.rfe.2004.08.004

Harlin, J. L. (1992). The Aging Family Farm - Estate/Succession Planning for Farmers. Agricultural Finance, 34, 38-39.

Harris J. M., \& Mishra, A. K. (2019). US Trends in Farm and Off-Farm Rural Employment. Rural Policies and Employment, 207-220. https://doi.org/10.1142/9781786347091_0013 
Hoppe, R. A., \& Korb, P. (2006). Understanding U.S. Farm Exits. USDA, Economic Research Service, Economic Research Report No. 21. 10.22004/ag.econ.7212

Huffman, W. E. (1980). Farm and Off-Farm Work Decisions: The Role of Human Capital. The Review of Economics and Statistics, 62(1), 14-23. DOI: 10.2307/1924268

Katchova, A. L., \& Ahearn, M. (2017). Farm Entry and Exit from US Agriculture. Agricultural Finance Review, 77(1), 50-63. https://doi.org/10.1108/AFR-03-2016-0021

Kazukauskas, A. C. Newman, D. C., \& Sauer, J. (2013). Disinvestment, Farm Size, and Gradual Farm Exit: The Impact of Subsidy Decoupling in a European Context. American Journal of Agricultural Economics, 95(5), 1068-1087. https://doi.org/10.1093/ajae/aat048

Key, N., \& Roberts, M. J. (2006). Government Payments and Farm Business Survival. American Journal of Agricultural Economics, 88(2), 382-92. https://doi.org/10.1111/j.1467-8276.2006.00865.x

Kimhi, A. (1994). Participation Of Farm Owners In Farm And Off-Farm Work Including The Option Of Full-Time Off-Farm Work. Journal of Agricultural Economics, 45, 232-239. https://doi.org/10.1111/j.1477-9552.1994.tb00397.x

Kimhi, A., \& Bollman, R. (1999). Family Farm Dynamics in Canada and Israel: The Case of Farm Exits. Agricultural Economics, 21, 69-79. https://doi.org/10.1016/S0169-5150(99)00015-8

Kimhi, A., \& Lopez, R. (1999). A Note on Farmers' Retirement and Succession Considerations: Evidence from a

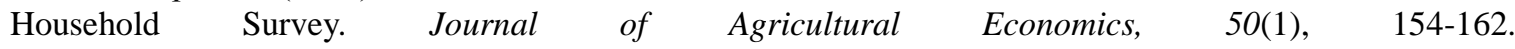
https://doi.org/10.1111/j.1477-9552.1999.tb00802.x

Kuehne, J. (2012). My Decision to Sell the Family Farm. Agriculture and Human Values, 30(2), 1-30. https://doi.org/10.1007/s10460-012-9393-7

Lee, J., Nadolnyak, D., \& Hartarska, V. (2017). The Effect of Weather on Agricultural Labor Supply. Journal of Agribusiness, 35(1), 15-27. https://doi.org/10.2139/ssrn.3104156

Li, S., Nadolnyak, D., \& Hartarska, V. (2019). Agricultural Land Conversion: Impacts of Economic and Natural Risk Factors in a Coastal Area. Land Use Policy, 80(1), 380-390 https://doi.org/10.1016/j.landusepol.2018.10.016

Luis, M., Carter, L., Alfons, O. L., \& Helmut, S. (2018). Factors influencing the stay-exit intention of small livestock farmers, empirical evidence from southern Chile. Spanish Journal of Agricultural Research, 16(1). https://doi.org/10.5424/sjar/2018161-10806

May, D., Arancibia, S., Behrendt, K., \& Adams, J. (2019). Preventing young farmers from leaving the farm: Investigating the effectiveness of the young farmer payment using a behavioural approach. Land Use Policy, 82, 317-327. https://doi.org/10.1016/j.landusepol.2018.12.019

Mishra, A. K., \& El-Osta, H. S. (2008). Effect of Agricultural Policy on Succession Decisions of Farm Households. Review of Economics of the Household, 6(3), 285-307. https://doi.org/10.1007/s11150-008-9032-7

Mishra, A. K., El-Osta, H. S., \& Shaik, S. (2010). Succession Decisions in U.S. Family Farm Businesses. Journal of Agricultural and Resource Economics, 35(1), 133-152. https://doi.org/10.22004/ag.econ.61055

Mishra, A. K., Mishra, J. M. F., \& Joo, H. (2014). Off-Farm Work, Intensity of Government Payments, and Farm Exits: Evidence from a National Survey in the United States. Canadian Journal of Agricultural Economics, 62(2), 283-306. https://doi.org/10.1111/cjag.12027

Nadolnyak, D., Hartarska, V., \& Griffin, B. (2019). The Impacts of Economic, Demographic, and Weather Factors on the Exit of Beginning Farmers in the United States. Sustainability, 11, 4280. https://doi.org/10.3390/su11164280

Nadolnyak, D., Hartarska, V., \& Shen, S. (2016). Climate Variability \& Agricultural Loan Delinquency in the US. International Journal of Economics and Finance, 8(9), 238-249. https://doi.org/10.5539/ijef.v8n12p238

Nadolnyak, D., Hartarska, V., \& Shen, S. (2017). Farm Credit System Credit and Farm Income and Output. Agricultural Finance Review, 77(1), 95-110. https://doi.org/10.1108/AFR-03-2016-0020

Newman, J., \& McGroarty, P. (2017). The Next American Farm Bust is Upon Us. The Wall Street Journal, 8, 2017. 
Peel, D., Schirmer, J., Berry, H., \& O’Brien, L. V. (2019). Farm exit, wellbeing and autonomy: A quantitative analysis of exited farmers in Australia. Rural Society, 28(2), 108-126. https://doi.org/10.1080/10371656.2019.1645426

Pesquin, C., Kimhi, A., \& Kislev, Y. (1999). Old Age Security and Inter-Generational Transfer of Family Farms. European Review of Agricultural Economics, 26(1), 19-37. https://doi.org/10.1093/erae/26.1.19

Pietola, K., Minna, V., \& Alfons, O. L. (2003). Timing and Type of Exit from Farming: Farmers' Early Retirement Programmes in Finland. European Review of Agricultural Economics, 30(1), 99-116. https://doi.org/10.1093/erae/30.1.99

Quaye, F., Nadolnyak, D., \& Hartarska, V. (2018). Climate Change Impacts on Farmland Values in the Southeast. Sustainability, 10(10), 3426. https://doi.org/10.3390/su10103426

Stokes, J. R. (2006). Entry, Exit, and Structural Change in Pennsylvania's Dairy Sector. Agricultural and Resource Economics Review, 35(2), 357. https://doi.org/10.1017/S1068280500006791

Tauer, L. W. (1985). Use of Life Insurance to Fund the Farm Purchase from Heirs. American Journal of Agricultural Economics, 67(1), 60-69. https://doi.org/10.2307/1240824

Tauer, L. W. (2006). When to Get In and Out of Dairy Farming: A Real Option Analysis. Agricultural and Resource Economics Review, 35(2), 339-347. https://doi.org/10.1017/S1068280500006778

Tweeten, L., \& Carl, R. Z. (1994). Is farm operator succession a problem? Choices, 9(2), 33-35. https://www.jstor.org/stable/43602396

Van Asseldonk, M. A. P. M., van der Veen, H. B., \& van der Meulen, H. A. B. (2010). Retirement Planning by Dutch Farmers: Rationality or Randomness? Agricultural Finance Review, 70(3), 365-376. https://doi.org/10.1108/00021461011088495

Viaggi, D. (2019). Entry and Exit of Farmers Across the EU. Rural Policies and Employment, 197-206. https://doi.org/10.1142/9781786347091_0012

\section{Notes}

Note 1 . While farmers, like everybody else, are eligible for social security at the age of 65 if they have paid into it, we define the age group as older than 60 years. This helps capturing possible disinvestment in preparation for retirement and can help understand whether farmers plan their retirement by taking advantage of favorable market conditions and sell land before they exit at 65 or later. Sensitivity analysis shows no significant differences when the age cutoff was varied from 60 to 65 years.

Also, to exclude hobby farmers some of whom may be of retirement age, we include only farms with annual sales of more than $\$ 50,000$.

Note 2. The goal of this disinvestment benchmark is to capture the retirement intent. Using several alternative values with the precise average of sold land or slightly higher percentages does not change the results substantially. While it is also possible to simply run a pooled OLS on the actual land divestiture, the objective is to capture the anticipation of retirement rather than to estimate how various factors affect the sale of land.

Note 3. Livestock is a dummy indicating that farm received the majority of its revenue from Hogs, Dairy products, Cattle, Sheep, and Goat Products, Equine, or Poultry and Eggs.

Note 4. Since we do not observe the farmers who exited in the 5 year period when their exit becomes apparent, similar comparison between the exited and remaining farmers is less meaningful.

Note 5. The marginal effect at the mean can technically be computed but, at this point, our access to the Census Data has been terminated.

Note 6. This large impact must be considered in the context that the actual change in the non-agricultural sector share between 1997 and 2007 was 0.1 percent.

\section{Copyrights}

Copyright for this article is retained by the author(s), with first publication rights granted to the journal.

This is an open-access article distributed under the terms and conditions of the Creative Commons Attribution license (http://creativecommons.org/licenses/by/4.0/). 